\title{
Pengujian Dissipation Factor pada Transformator dengan Jumper dan tanpa Jumper Bushing
}

\author{
Luqi Abidin
}

\author{
PT PLN (Persero) UPDL PADANG \\ luqiabidin1@gmail.com
}

\begin{abstract}
Dissipation Factor or Tan delta $(\delta)$ is one of the testing methods to find out the transformer isolation conditions, but in its use two different measurement procedures appear, the first measurement using jumpers is maximized for equalizing current flow (parallel), the second without jumpers assume that inside the turns already connected so that there is no need to use jumpers anymore, to find out which testing procedures produce more valid data testing is done with 2 different variables, first testing the frequency changes second to changes in voltage, the average test results obtained value of the dissipation factor for the use of jumpers $0.5 \%$ whereas without a jumper 30\%, from this it can be concluded that without a jumper results in additional dielectric losses from each phase and also the current flowing in the circuit without a jumper is more resistive, resulting in high values and resulting in lower sizes become invalid
\end{abstract}

Keywords: Dissipation factor, Tan delta $(\delta)$

\begin{abstract}
ABSTRAK
Dissipation Factor atau Tan delta $(\delta)$ merupakan salah satu metode pengujian untuk mengetahui kondisi isolasi transformator, namun dalam penggunaannya muncul 2 prosedur pengukuran yang berbeda, pertama pengukuran menggunakan jumper dimaksutkan untuk pemerataan aliran arus(paralel), yang kedua tanpa jumper beranggapan bahwa didalam belitan sudah terhubung sehingga tidak perlu menggunakan jumper lagi, untuk mengetahui prosedur pengujian mana yng menghasilkan data lebih valid dilakukan pengujian dengan 2 variabel berbeda, pertama pengujian terhadap perubahan frekuensi yang kedua terhadap perubahan tegangan, rata-rata hasil pengujian didapatkan nilai dissipation factor untuk pemakaian jumper sebesar $0.5 \%$ sedangkan tanpa jumper $30 \%$, dari sini dapat disimpulkan bahwa tanpa jumper mengakibatkan tambahan dielectric losses dari masing-masing fasa dan juga arus yang mengalir pada rangkain tanpa jumper lebih bersifat resistif, sehingga mengakibatkan nilainya menjadi tinggi dan mengakibatkan pengukuran menjadi tidak valid.
\end{abstract}

Kata kunci: Dissipation factor, Tan delta $(\delta)$ 


\section{PENDAHULUAN}

Transformator memerupakan salah satu peralatan lsitrik yang sangat vital dalam penyaluran energi listrik, untuk meminimalisir adanya kegagalan transformator pada saat beroperasi[1], ada banyak metode pengujian yang digunakan untuk menentukan kondisi transformator, mulai dari pengujian kualitas minyak, kadar air, kadar asam, partial discharge, tahanan isolasi, tan delta dan masih banyak lagi[2], semua metode ini mempunyai tujuan sama yaitu menghasilkan diagnosa yang akurat, ada banyak sekali faktor yang mempengaruhi akurasi hasil pengujian mulai kondisi alat ukur, kondisi lingkungan, kemampuan dari operator, prosedur pengujian dan lain sebagainya, kesalahan data data pengujian dapat menyebabkan kerugian baik segimatrial dan inmaterial, dalam hal ini penulis akan membahas terkait metode pengujian tan delta pada transformator.

Tan delta atau dissipation factor merupakan jenis metode pegujian untuk mengetahui kondisi isolasi dari transformator[2], ada 2 persepsi terkait cara pengukuran metode ini yaitu penggunaan kabel jumper pada masing-masing busing dan tidak, oleh karena hal itu perlu dilakukan kajian terhadap 2 persepsi cara pengukuran ini.

\section{DASAR TEORI}

\subsection{Power Factor (Cos $\theta$ ) dan Dissipation Factor (Tan $\delta)$}

Dalam pengujian peralatan elektronik pengukuran arus bocor digunakan sebagai acuan untuk mengukur tingkat isolasi dari sebuah peralatan elektronik, cosinus sudut antara arus yang terukur pada isolasi dengan tegangannya disebut dengan power factor[3], dalam kondisi ideal tanpa adanya rugi-rugi sebuah isolasi memiliki sudut $90^{\circ}$ dalam hubungan tegangan dan arus, hal ini dapat diartikan bahwa isolasi yang ideal memiliki power factor $\left(\operatorname{Cos}\left(90^{\circ}\right)\right)=0$, namun dalam realitanya tidak ada isolasi yang sempurna mampu menghasilkan sudut $90^{\circ}[3]$.

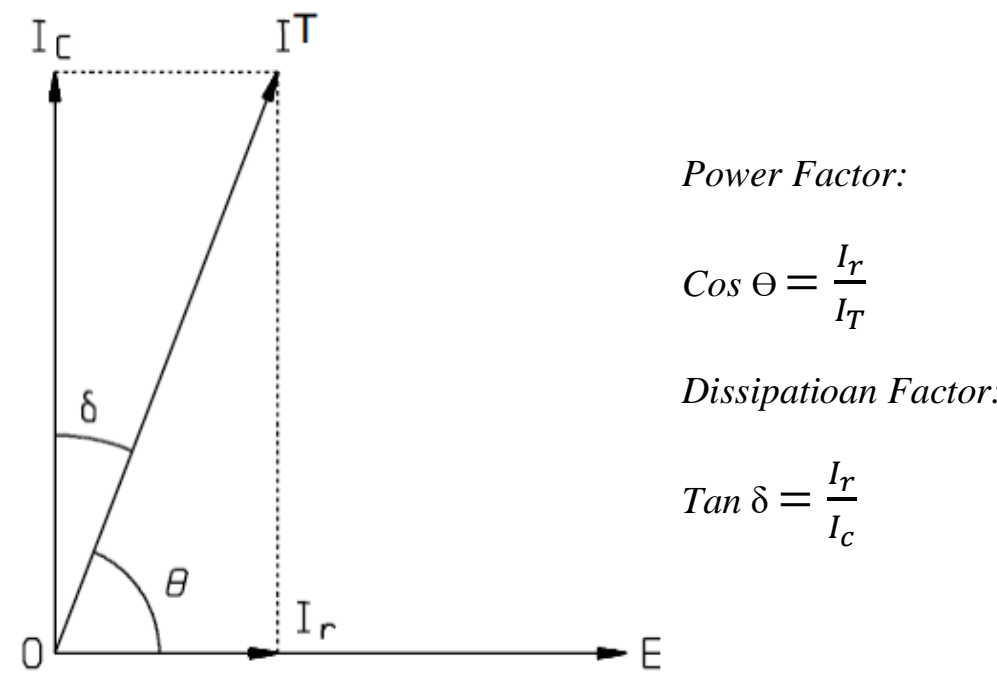

Gambar 1. Diagram Vektor Power Factor \& Dissipation Factor

Delta $(\delta)$ adalah sudut rugi-rugi yang terbentuk ketika sebuah arus yang terukur dari isolasi yang tidak ideal atau kurang dari sudut $90^{\circ}(90-\Theta)$, arus yang menghasilkan sudut $90^{\circ}$ bersifat kapasitif $\left(\mathrm{I}_{\mathrm{C}}\right)$, namun dalam realitanya terdapat arus yang bersifat resistif $\left(\mathrm{I}_{\mathrm{R}}\right)$ yang membuat sudut yang dihasilkan kurang dari $90^{\circ}[3]$, dalam hal ini dapat dikatakan semaikin tinggi nilai kapasitansi semakin bagus nilai isoalsi dari perangkat elektronik, dan Tan Delta $(\delta)$ delta adalah sebuah metode yang digunakan untuk mengukur nilai kapasitasnsi sebuah isolasi dari perangkat elektronik. 


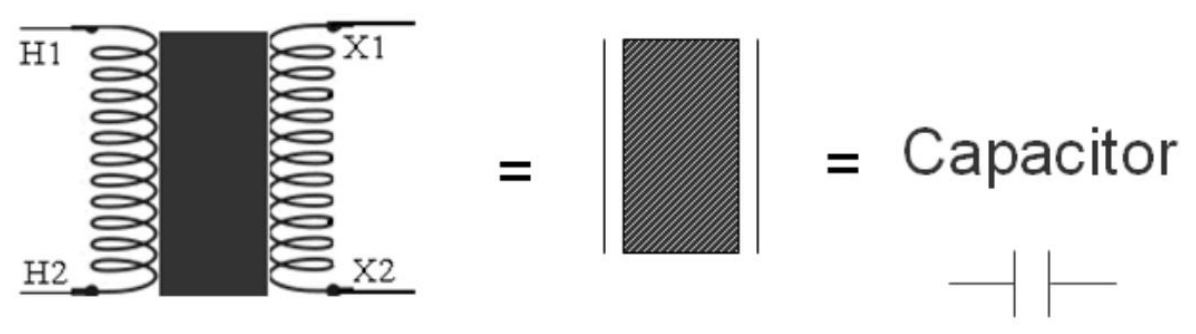

Gambar 2. Kapasitansi

Dari teori diatas metode pengujian Tan Delta $(\delta)$ dapat digunakan untuk mengukur tingkat isolasi dari transformator, sebuah isolasi dikatakan bagus jika bersifat kapasitif, pada transformator terdapat 3 bagian yang dapat diukur nilai kapasitasinya yaitu kapasitansi High Voltage ke Low Voltage $\left(\mathrm{C}_{\mathrm{HL}}\right)$, Kapasitansi High Voltage ke Ground $\left(\mathrm{C}_{\mathrm{HG}}\right)$ dan Kapasitansi Low Voltage ke Ground $\left(\mathrm{C}_{\mathrm{LG}}\right)[3]$.

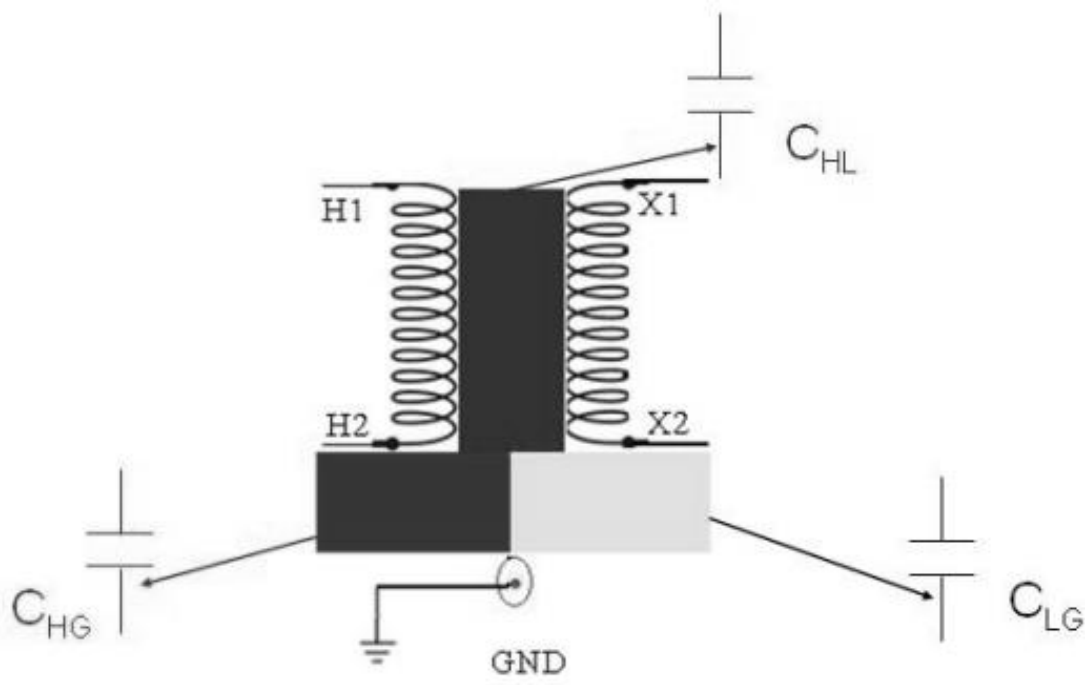

Gambar 3. Kapasitansi Transformator

Dari 3 bagian pengukuran nilai kapasitansi antar belitan $\left(\mathrm{C}_{\mathrm{HL}}\right)$ memiliki factor koreksi yang cukup kecil karena tidak terpengaruhi oleh kontaminasi dari permukaan luar[1], sedangkan pada bushing High Voltage $\left(\mathrm{C}_{\mathrm{HG}}\right)$ dan bushing Low Voltage $\left(\mathrm{C}_{\mathrm{LG}}\right)$ kontaminasi pada permukaan akibat debu, kotoran, dll dapat mempengaruhi hasil pengukuran, berikut adalah standart nilai Dissipation Factor (Tan Delta ( $\delta)$ ) menurut Doble (ANSI C 57.12.90):

Tabel 1. Doble (ANSI C 57.12.90)

\begin{tabular}{|c|c|}
\hline Nilai Tan Delta (ס) & Kategori \\
\hline$<0.5 \%$ & Bagus \\
\hline $0,5 \%>\mathrm{x}<0,7 \%$ & Cukup \\
\hline $0,7 \%>\mathrm{x}<1 \%$ & Investigasi \\
\hline$>1 \%$ & Buruk \\
\hline
\end{tabular}




\subsection{Jenis-Jenis Mode Pengukuran Dissipation Factor (Tan ס)}

Dalam pengujian transformator terdapat beberapa yaitu GST (pengukuran total kapasitansi peralatan), UST (pengukuran diperoleh dari perangkat yang sejenis), GSTg (pengukuran diperoleh dari perngakat dengan ground), dari setiap mode nilai yang kapasitansi yang dikur berbeda-beda, berikut adalah tabel pengukuran mode pengujian Tan $\boldsymbol{\delta}$ [4]:

Tabel 2. Mode Pengujian Tranformartor

\begin{tabular}{|l|l|l|}
\hline \multicolumn{1}{|c|}{$\begin{array}{c}\text { Mode } \\
\text { Pengujian }\end{array}$} & \multicolumn{1}{|c|}{$\begin{array}{c}\text { Transformator } \\
\text { 2 Kumparan }\end{array}$} & \multicolumn{1}{|c|}{$\begin{array}{c}\text { Transformator } \\
\text { 3 Kumparan }\end{array}$} \\
\hline UST A & $\mathrm{C}_{\mathrm{HL}}$ & $\mathrm{C}_{\mathrm{HL}}$ \\
\hline UST B & & $\mathrm{C}_{\mathrm{HT}}$ \\
\hline UST A+B & $\mathrm{C}_{\mathrm{HL}}$ & $\mathrm{C}_{\mathrm{HL}}+\mathrm{C}_{\mathrm{HT}}$ \\
\hline GST & $\mathrm{C}_{\mathrm{HL}}+\mathrm{C}_{\mathrm{HG}}$ & $\mathrm{C}_{\mathrm{HL}}+\mathrm{C}_{\mathrm{HT}}+\mathrm{C}_{\mathrm{HG}}$ \\
\hline GSTg A & $\mathrm{C}_{\mathrm{HL}}+\mathrm{C}_{\mathrm{HG}}$ & $\mathrm{C}_{\mathrm{HL}}+\mathrm{C}_{\mathrm{HG}}$ \\
\hline GSTg A & $\mathrm{C}_{\mathrm{HG}}$ & $\mathrm{C}_{\mathrm{HT}}+\mathrm{C}_{\mathrm{HG}}$ \\
\hline GSTg A+B & $\mathrm{C}_{\mathrm{HG}}$ & $\mathrm{C}_{\mathrm{HG}}$ \\
\hline
\end{tabular}

*Catatan: $\mathrm{C}_{\mathrm{HT}}=$ Kasitansi terhadap tertier

Pada pengujian PF maupun DF sebaiknya menggunakan tegangan uji sebesar 10kV[3] mendapatkan hasil yang bagus, hal ini dikarenakan semakin tinggi tegangan uji ionisai pada perangkat isolasi dan tidak merusak perangkat elektronik, akan tetapi semakin kecil tegangan uji akan semakin sulit menganalisa hasil pengujian, berikut adalah merupakan hasil pengujian.

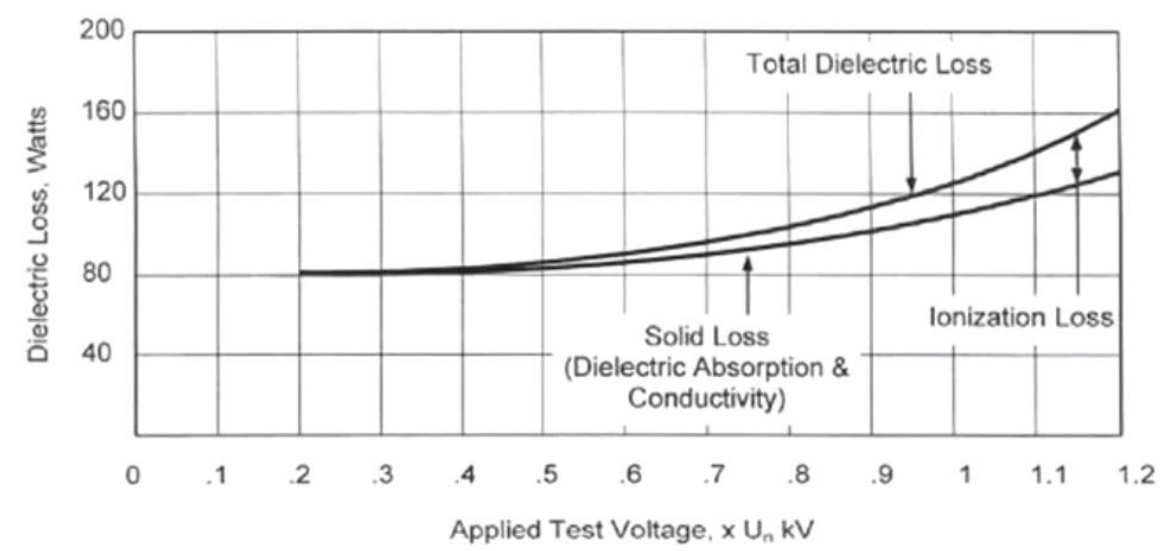

Gambar 4. Dielectric losses terhadap nilai tegangan

\section{HASIL DAN PEMBAHASAN}

Dalam pengujian Tan $\delta$ terhadap transformator terdapat 2 persepsi terkait prosedur pengujianya pertama pengujian $\tan \delta$ harus menyambungkan antar fasa pada sisi high voltage maupun low voltage, yang kedua adalah tanpa jumper sama sekali, masing-masing persepsi memilik alasanya masing-masing pertama jumper antar fasa dibuat untuk memertakan tegangan uji dari perangkat uji (parale) sehingga hasil uji dapat dikatakan bisa mewakili dari kesuluruhan transformator, sedangkan yang kedua beranggapan bahwa masing-masing belitan didalam transformator sudah terhubung baik secara delta $(\Delta)$ maupun star $(\mathrm{Y})$, hal ini dirasa pemasangan 
jumper antar fasa tidak diperlukan karena hasil dari kedua pengukuran ini pasti sama karena sudah terhubung dari dalam.

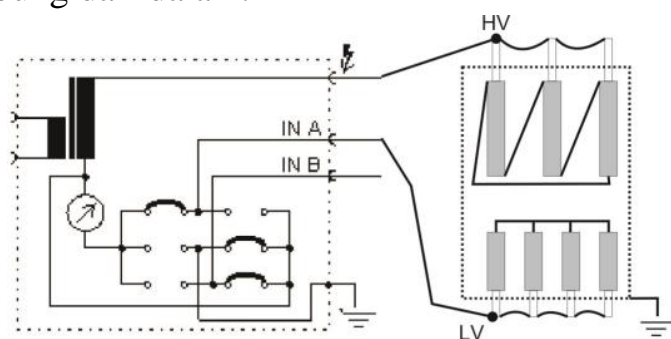

(a) Dengan jumper

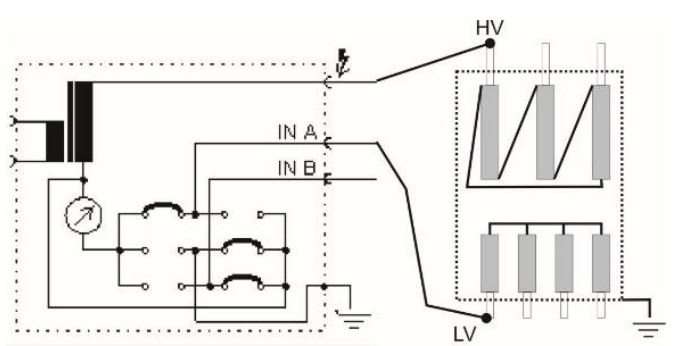

(b) Tanpa jumper

Gambar 5. Rangkain Pengukuran Tan $\delta$

Pengujian dilakukan pada transformator 2 kumparan dengan menggunakan mode UST, mode ini menghasil pengukuran kapasitansi antara high voltage dengan low voltage $\left(\mathrm{C}_{\mathrm{HL}}\right)$, pengambilan nilai kapasitansi $\mathrm{C}_{\mathrm{HL}}$ dikarenakan nilainya tidak terpengaruh kontaminasi dari external karena posisinya berada didalam transformator, dan diharapkan hasil yang diperoleh lebih valid dibanding dengan pengukuran kapasitansi yang lain.

Pengujian dilaksanakan sebanyak 2 kali dengan merubah variable frekuensi dan tegangan, perubahan frekuensi merepresentasikan pengujian terhadap partial discharge, semakin tinggi frekwensi berarti semakin tinggi nilai partial discharge pada peralatan uji, pengujian frekuensi dimulai dari frekuensi dari $15 \mathrm{~Hz}$ sampai dengan $400 \mathrm{~Hz}$, pengujian kedua terhadap tegangan, hal ini merepresentasikan tegangan tembus dari perangkat isolasi, pengujian dimulai dari nilai $2 \mathrm{kV}$ sampai dengan tegangan $12 \mathrm{kV}$, dan berikut ini adalah grafik dan data hasil pengujiannya.

\section{Frekuensi (Hz)}

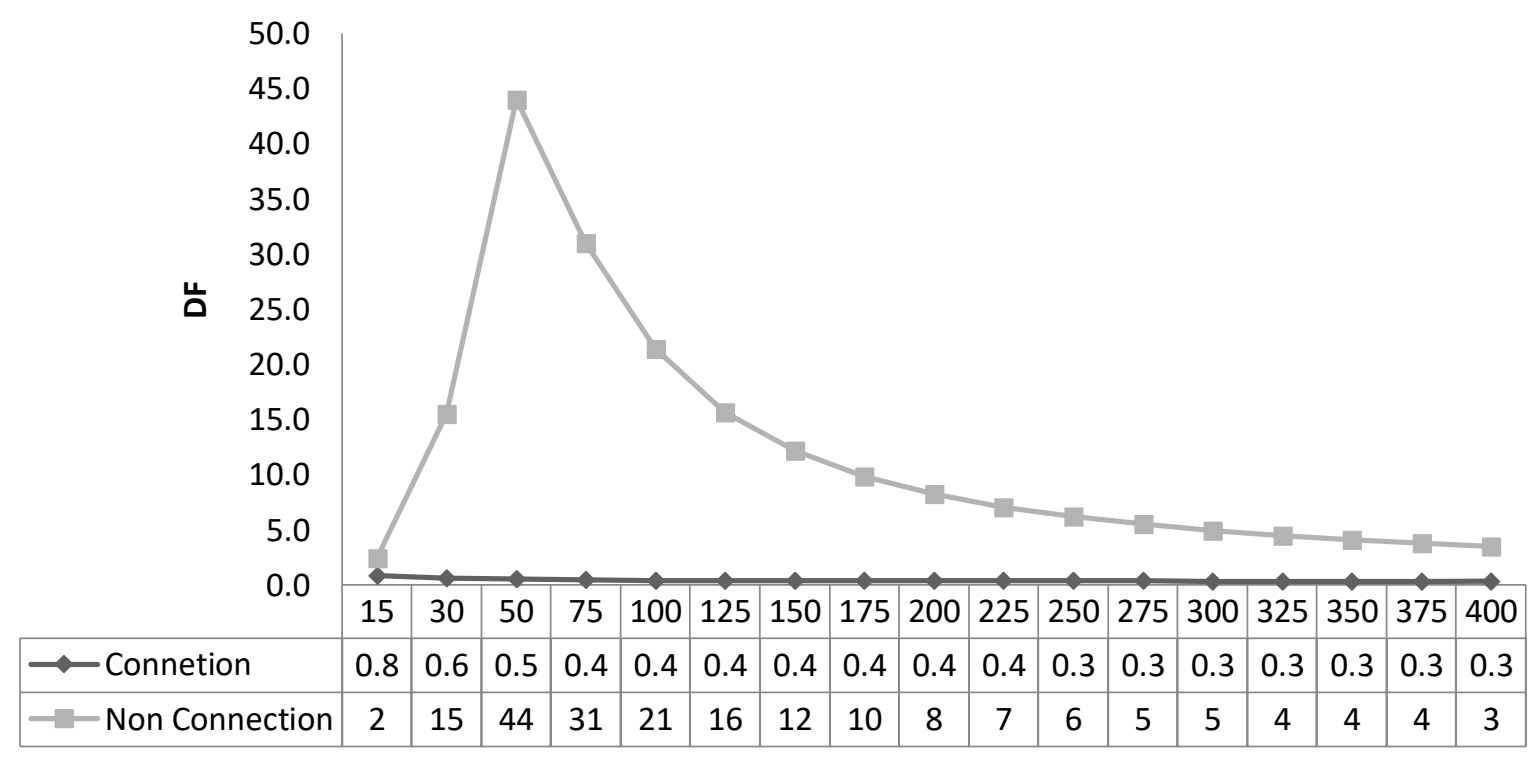

Gambar 6. Nilai DF Terhadap perubahan frekuensi $(\mathrm{Hz})$ pengujian 


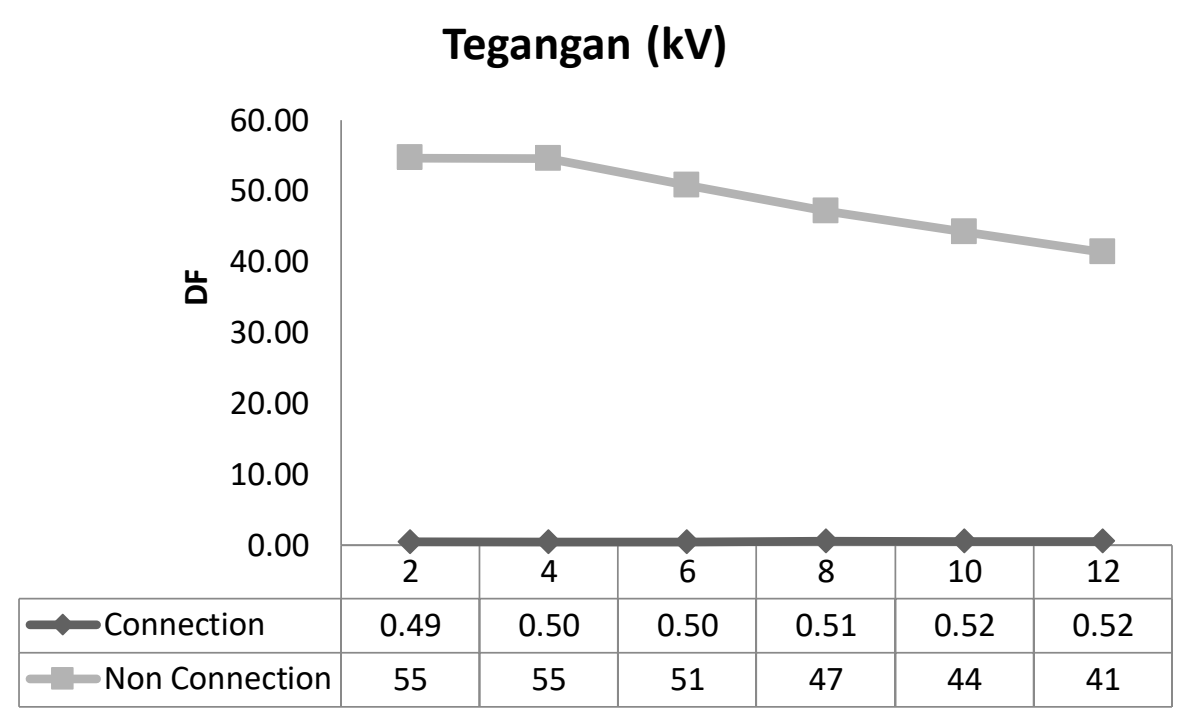

Gambar 7. Nilai DF Terhadap perubahan Tegangan (kV)

Pada pengujian frekuensi dan tegangan terdapat perbedaan yang cukup jauh pada nilai $\tan \delta$ dari masing-masing prosedur pengujian, dengan selisih rata-rata 40 poin, hal ini dapat dijelaskan dengan dengan menggunakan perhitungan matematis Power Factor dan Dissipation Factor, sehingga didapatkan nilai arus kapasitif dan arus resistif dari kedua jenis pengukuran.

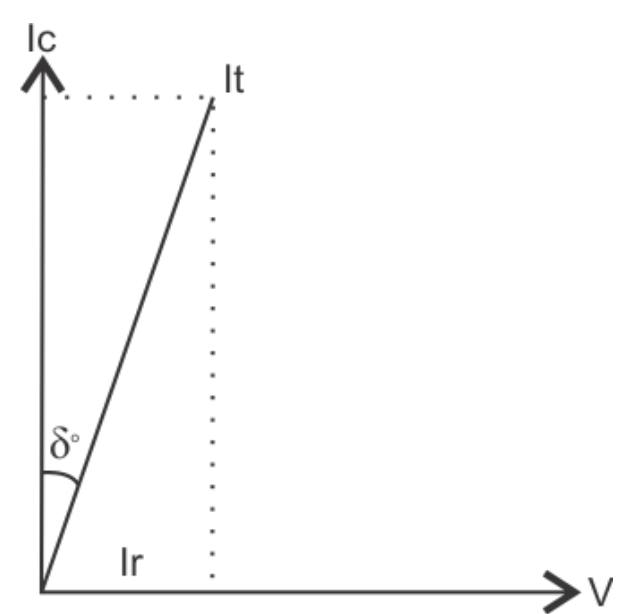

(a) Dengan Jumper

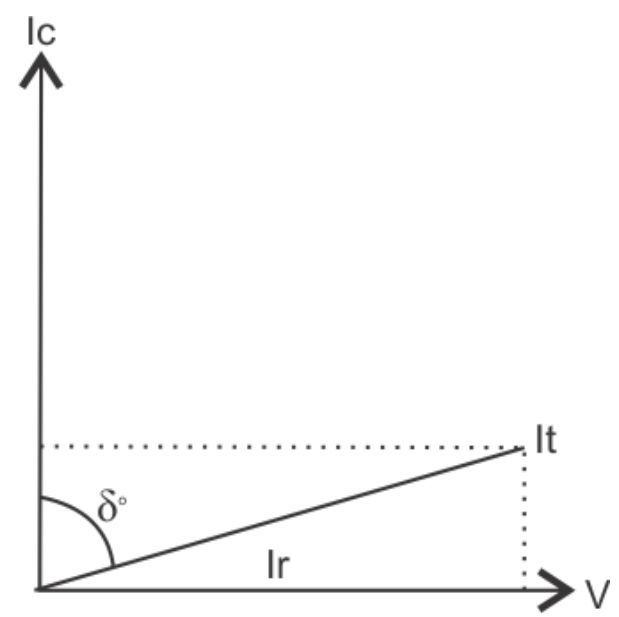

(b) Tanpa Jumper

Gambar 8. Diagram Vektor 2 Prosedur Pengujin

Diagram vector hasil pengujian menunjukan prosedur pengujian pertama (dengan jumper) arus bocor yang teredektsi lebih bersifat kapasitif, sehingga menghasilkan nilai tan $\delta$ nya cenderung kecil, sedangkan prosedur pengujian kedua (tanpa jumper) lebih bersifat resistif, hal ini yang mengakibatkan nila tan $\delta$ yang didapat lebih besar, sekarang yang menjadi pertanyaan dari kedua prosedur ini adalah pengujian mana yang menghasilkan data yang valid, apakah yg pertama atau yang kedua, secara garis sebenarnya hal ini sudah dapat disimpulkan bahwa prosedur yang menghasilkan data yg valid adalah percobaan pertama, dikarenakan pengujian ini menggunakan transformator baru dan belum pernah digunakan, namun hal ini masih belum bisa menjelaskan alasan 
pemakaian prosedur ini, penjelasan secara teorinya pada percobaan pertama arus mengalir pada masing-masing bushing menuju kebelitan transformator kemudian mengalir pada low voltage bushing, arus yang mengalir ini lah yang dimaksud dengan dielectric losses.

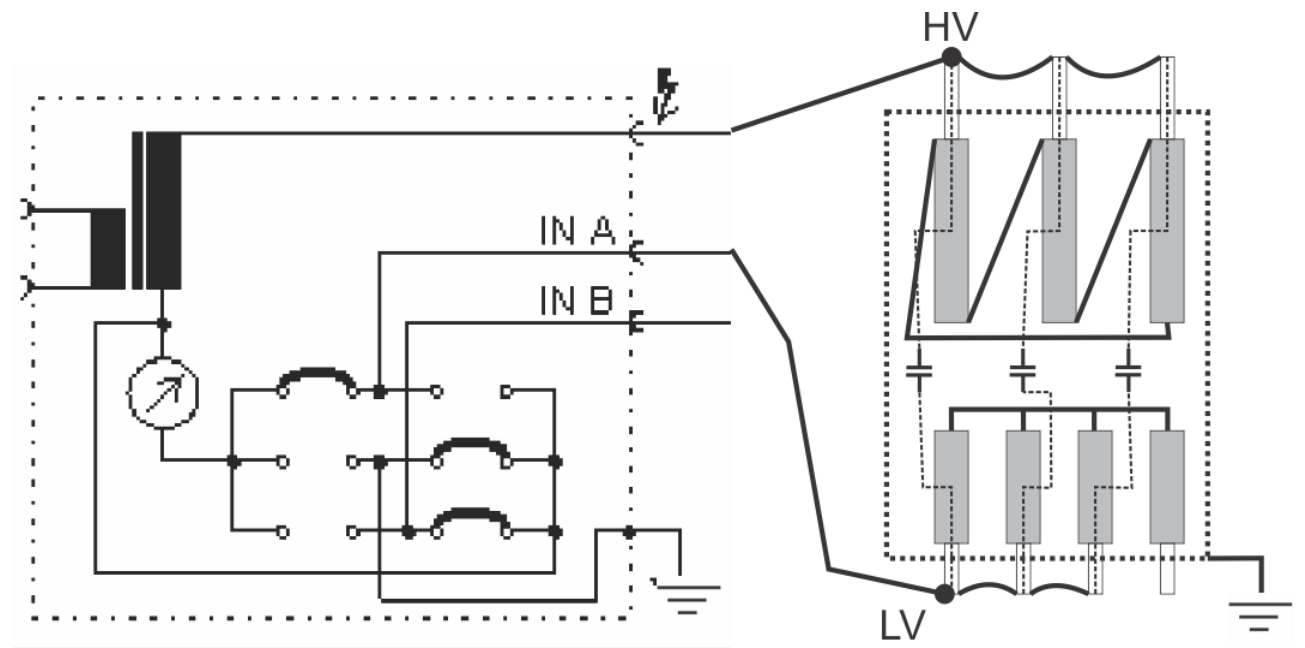

Gambar 9. Dengan jumper

Sedangkan pada percobaan kedua, ketika jumper antar fasa pada bushing dilepas, arus akan cenderung mengalir pada sisi low voltage terlebih dahulu, kemudian sisanya akan mengalir pada masing-masing fasa, arus yang terakhir ini nantikanya akan menjadi tambahaan losses pada saat pengukuran, mengakibatkan pengukruan $\tan \delta$ menjadi lebih besar dari seharusnya.

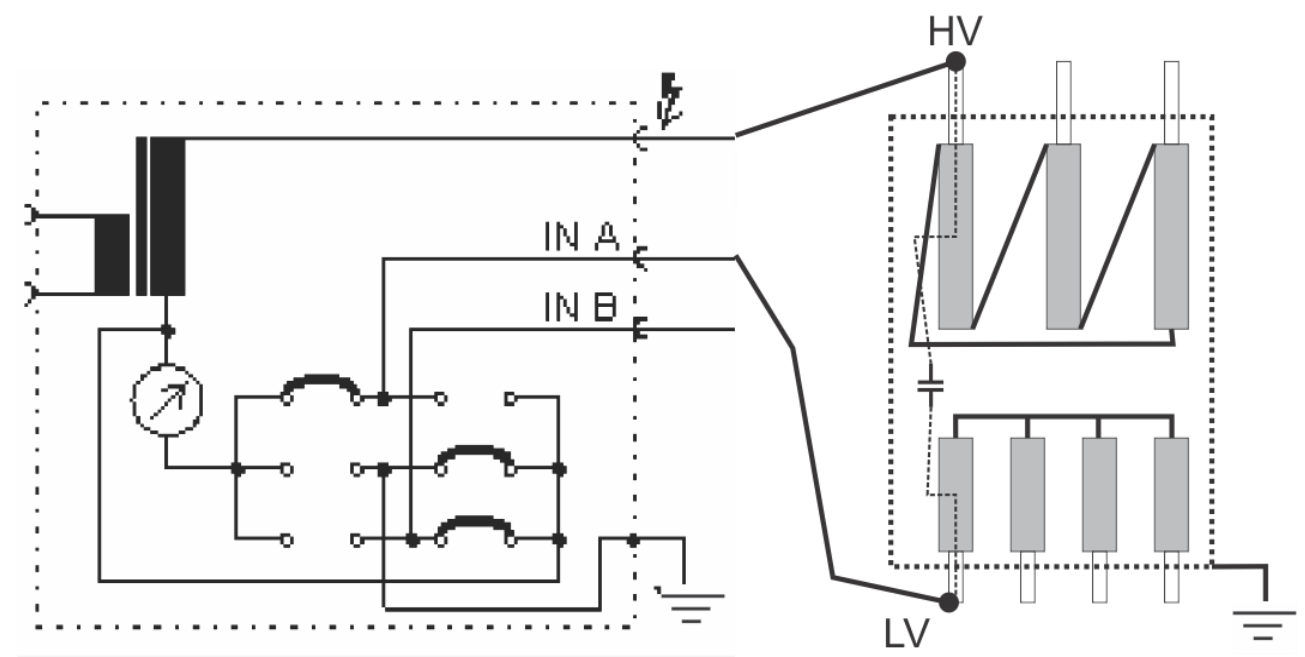

Gambar 10. Tanpa Jumper

\section{KESIMPULAN DAN SARAN}

Dari hasil pengujian dan pembahasan dapat disimpulkan bahwa:

1. Pengujian $\tan \delta$ dapat digunakan untuk mengetahui tingkat isolasi dari transformator tegangan tinggi maupun tegangan menengah

2. Tegangan uji untuk pengujian Power Factor idealnya adalah $10 \mathrm{kV}$

3. Pengujian Power factor dan Dissipatioan Factor harus menggunakan jumper/jumper antar fasa untuk menghasilakan data yang lebih valid. 


\section{DAFTAR PUSTAKA}

[1] M. EMMY, "Eksplorasi TanDelta Koreksi Suhu.” PLN P3B Region Jawa Bali, p. 13, 2016.

[2] B. P. Pemeliharaan, "Buku Pedoman Trafo Tenaga," 2014.

[3] D. Chhajer, "Power Factor Insulation Diagnosis," Megger, 2014.

[4] E. Onal, "A study for examining dissipation factors of various insulations and test transformers in the wide range of frequency," Elektron. ir Elektrotechnika, vol. 5, no. 5, pp. 27-32, 2012. 